\title{
Contemporary gully erosion trend in the northern part of the forest-steppe zone of the Russian Plain: a case study from the Republic of Tatarstan, European Russia
}

\author{
Aidar Sharifullin ${ }^{1}$, Artur Gafurov ${ }^{1}$, Regina Medvedeva $^{1}$, Valentin Golosov ${ }^{1,2,3}$, Aleksandr Dvinskih ${ }^{1}$, \\ Artem Gusarov $^{1}$, and Benedict Essuman-Quainoo ${ }^{1}$ \\ ${ }^{1}$ Institute of Environmental Sciences, Kazan Federal University, 18 Kremlyovskaya street, \\ Kazan, 420008, Russia \\ ${ }^{2}$ Research Laboratory for Soil Erosion and Fluvial Processes, Lomonosov Moscow State University, \\ GSP-1, Leninskiye Gory street, Moscow, 119991, Russia \\ ${ }^{3}$ Institute of Geography, Russian Academy of Sciences, Staromonetny per., 29, Moscow, 119017, Russia
}

Correspondence: Aidar Sharifullin (luleo123@mail.ru)

Published: 1 August 2019

\begin{abstract}
This article presents results for gully head cut retreat rates (GHRR) in the Pre-Kama region (Republic of Tatarstan, Russia) based on monitoring (1984-1994 and 2015-2018) and the interpretation of high-resolution satellite images (2004-2014). The results suggested that the mean linear GHRR have reduced by about five times, from $1.6 \mathrm{~m}$ per year (1983-1994) to $0.4 \mathrm{~m}$ per year (2015-2018). The main reason for the significant decrease in gully erosion was the increase in winter-spring air temperatures, which resulted in a reduction in the depth of soil freezing and surface runoff. The impact of land use, as well as erosion control measures, which were implemented in the study area during the late 1980s and early 1990s, was found to be less important.
\end{abstract}

\section{Introduction}

The problem of erosion of agricultural land in Russia has existed since the end of the 19th century (Dokuchayev, 1949; Kern, 1928). Detailed studies of gully erosion were undertaken in the mid-20th century by a number of researchers (Dedkov, 1990; Stupishin et al., 1984; Zorina, 2006, etc.) in the central and eastern parts of the Russian Plain. In the east of the Russian Plain, a map of gully density based on topographic maps of different scales $(1: 100000,1: 50000$ and $1: 25000)$ was constructed for the period covering 1950 1970s. The first data for GHRR were obtained in 1953, based on the interpretation of aerial photographs. Unfortunately, continuous gully headcut retreat monitoring that was stopped in 1994.

In recent decades, the European territory of Russia (ETR) has seen both climate change and a change in land use associated with the collapse of the Soviet Union in 1991 (Apukhtin and Kumani, 2012; Ivanov et al., 2017, etc.). These changes could be expected to affect the intensity of gully erosion.
However, the absence of modern gully monitoring in the north of the forest-steppe zone does not provide a basis for drawing conclusions and, therefore, it is necessary to resume analysis. The purpose of this study is to provide a quantitative assessment of modern gully erosion rate on the arable lands of the Pre-Kama region of the Republic of Tatarstan, European Russia.

\section{Materials and methods}

The research area is located in the western part of the Pre-Kama region $\left(16620 \mathrm{~km}^{2}\right)$ of the Republic of Tatarstan (Fig. 1), between the Volga, Kama and Vyatka Rivers. The average altitude within the study area is $150 \mathrm{~m}$. Gully density ranges from 0.1 to $0.5 \mathrm{~km} \mathrm{~km}^{-2}$ (Golosov et al., 2018). The geological structure of the territory of the Western PreKama region is composed of Permian rocks (mainly limestones and dolomites) and Quaternary sediments (mainly aleurites and clays). The climate of the study area is continental, with warm summers and moderately cold winters. 

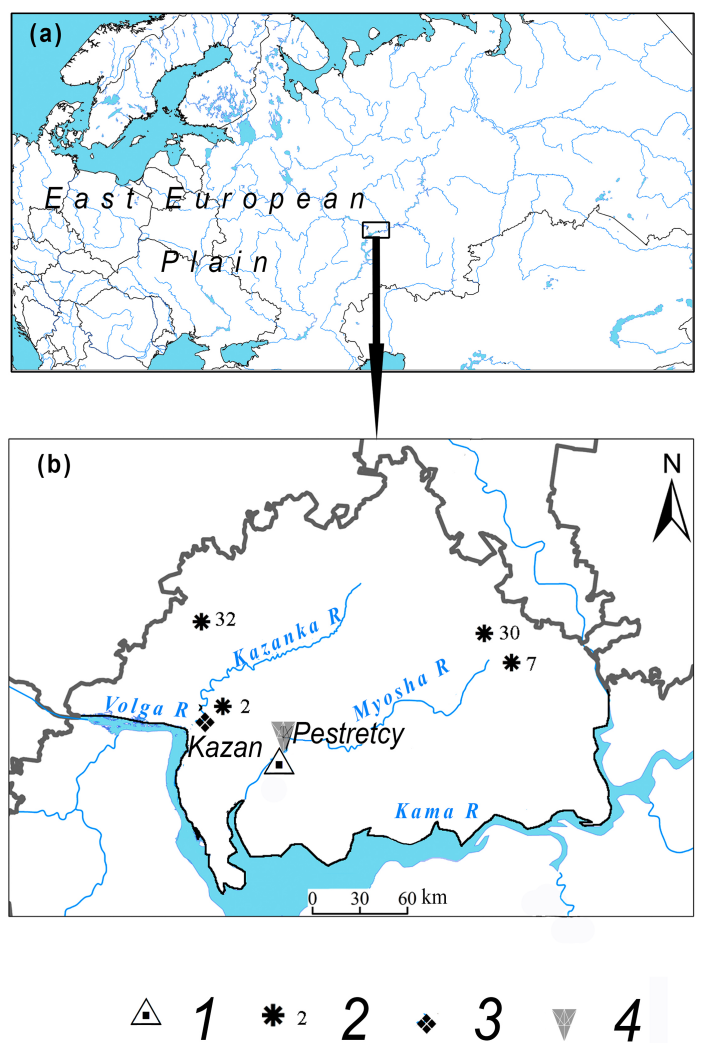

Figure 1. The location of the Pre-Kama region in the Russian Plain (a) and the Republic of Tatarstan (b). (Legend: 1 - the study region, 2 - the study sites with measurement of GHRR, based on the interpretation of high-resolution satellite images, 3 - the study sites with measurement of GHRR, based on a monitoring, 4 - the Kazan-Opornaya meteorological station, 5 - the Pestretcy gauging station (at the Myosha River).)

According to the Kazan weather station, the average annual temperature is $+4.1^{\circ} \mathrm{C}(1950-2017)$. The warmest month is July $\left(+19.8^{\circ} \mathrm{C}\right)$, and the coldest month is January $\left(-12^{\circ} \mathrm{C}\right)$. The annual average rainfall is $557 \mathrm{~mm}$, of which $69 \%$ falls in the warm season.

Gully erosion was investigated using two approaches: monitoring and interpretation of high-resolution satellite images. The headcuts of 48 gullies, located within four small catchments, were monitored from 1983 to 1994 . The monitoring stopped in 1995 and was re-launched in 2015. GHRR was determined once per year for 1983-1994 and twice per year (in May and September) for 2015-2018 by measuring the distance from the gully head to a fixed metal steak, placed upslope from gully head.

The interpretation of different-time satellite images was carried out for 2004 and 2014. Images were, taken from the WorldView-2, WorldView-3 and GeoEye satellites. The input images were first processed and standardized to a common scale and projection. In the next stage, thalwegs were digitized from images maded in 2004 and 2014 for each gully. Finally, the maps were overlain and the thalwegs used to calculate GHRR.

\section{Results}

Mean linear GHRR for the period 1983-1994 was estimated at $1.6 \pm 0.5 \mathrm{~m} \mathrm{yr}^{-1}$. During this time interval the highest GHRR were atypically associated with bottom gullies growth. For the period 2015-2018, the GHRR was estimated at $0.4 \pm 0.1 \mathrm{~m} \mathrm{yr}^{-1}$. A decrease in GHRR was therefore revealed for 2015-2018 compared to 1983-1994.

The linear GHRR for slope gullies according to satellite imagery were ranged from 0 to $3.4 \mathrm{~m} \mathrm{yr}^{-1}$ during 20042014 , with an average rate of $0.3 \mathrm{~m} \mathrm{yr}^{-1}$. At the same time, about $70 \%$ of all the gullies were found to exhibit inactive headcuts.

Previous studies conducted in the territory of the Western Pre-Kama have reported a slow attenuation in the growth rate of the gullies: $2 \mathrm{~m} \mathrm{yr}^{-1}$ in 1953-1958 (Stupishin et al., 1980), $0.8 \mathrm{~m} \mathrm{yr}^{-1}$ in 1958-1985 (Butakov et al., 1987), $1.6 \mathrm{~m} \mathrm{yr}^{-1}$ in $1983-1994,0.3 \mathrm{~m} \mathrm{yr}^{-1}$ in 2004-2014, and $0.4 \mathrm{~m} \mathrm{yr}^{-1}$ in 2015-2018.

On the East European Plain, about $80 \%$ of the increase in gullies is observed during the period of spring snowmelt. Therefore, meteorological parameters characterizing winterspring conditions (Table 1) need to be taken into account when interpreting data for GHRR. All of the parameters that were taken into account in this study are characterized by significant changes, especially over the recent decades. Thus, since the 1980s, there has been an increase in air temperature during the winter spring periods. Also, there has been an increase in precipitation and water storage in snow. However, the increase in precipitation almost did not affect the height of the snow cover. The observed changes in such winterspring meteorological parameters have generally good agreement with water flow characteristics in the Myosha River during the spring flood (Fig. 2). Thus, since the 1980s, maximum annual discharges and total water runoff depth in the basin during the spring have been decreased by $31 \%$. Therefore, it is very likely that the reduction of surface water runoff was the main reason for decreasing of the GHRR in the region.

One of the most significant human factors that influences gully erosion rates, by changing the structure of the upper soil layer (e.g. Valentin et al., 2004), is the area of cultivated land. However, there were no significant changes in the area of cultivated land in the Myosha River basin in 2015 compared to 1985 (Ivanov et al., 2017). The study area was actively ploughed even in the 1990s. The main crops grown are wheat, barley and corn. In the recent years, perennial grasses have also been introduced into rotations.

Another reason for the reduction in the GHRR in this region was the implementation of erosion control measures that began in the late 1970s. In total, about 120 erosion control 
Table 1. Some climatic characteristics for the study region $T_{\mathrm{aw}}$ - the mean long-term air temperature for the winter period (December to February), $T_{\mathrm{am}}$ - the mean long-term air temperature for March, $N$ - the number of days in the winter period with daily temperatures above $0{ }^{\circ} \mathrm{C}, \mathrm{A}$ - the duration of the cold period (the number of days with a stable average daily temperature below zero), $P-$ the mean long-term precipitation for the cold period, $H$ - the mean long-term snow depth for the winter period, $S$ - the average long-term water storage in the snow for the first decade of March.

\begin{tabular}{lrrrrrrr}
\hline Periods & $T_{\mathrm{aw}},{ }^{\circ} \mathrm{C}$ & $T_{\mathrm{am}},{ }^{\circ} \mathrm{C}$ & $N, \mathrm{~d}$ & $A, \mathrm{~d}$ & $P, \mathrm{~mm}$ & $H, \mathrm{~cm}$ & $S, \mathrm{~mm}$ \\
\hline $1980-1989$ & -10.1 & -5.6 & 2.6 & 154 & 167 & 29.1 & 96 \\
$1990-1999$ & -9.8 & -3.9 & 4.5 & 150 & 185 & 29.9 & - \\
$2000-2009$ & -8.7 & -2.7 & 7.7 & 138 & 200 & 29.0 & 134 \\
$2010-2018$ & -9.6 & -3.9 & 6 & 138 & 228 & 40.1 & 141 \\
\hline
\end{tabular}
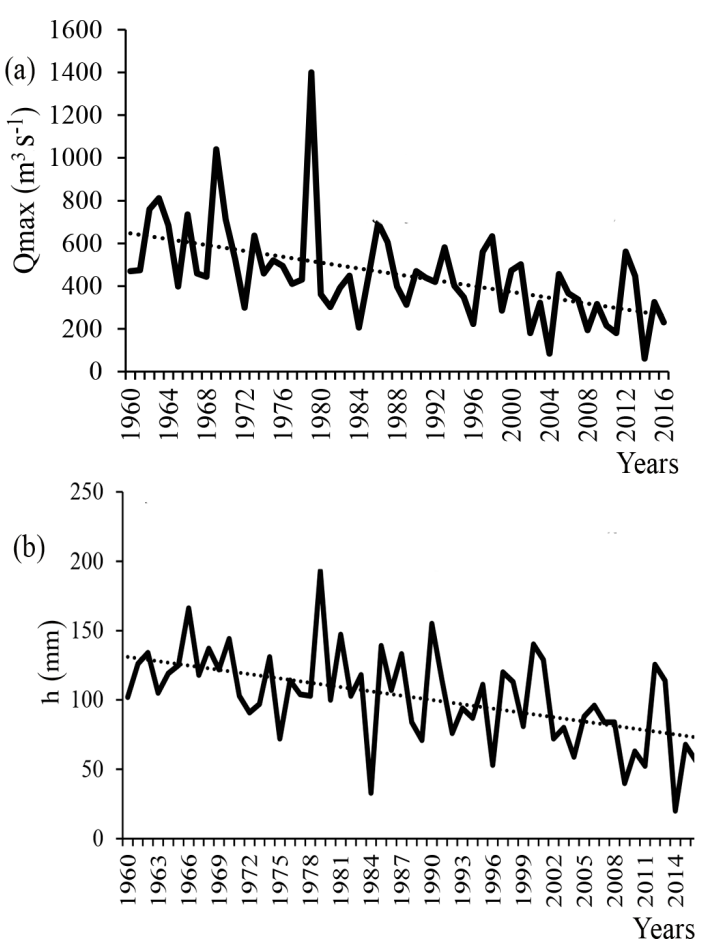

Figure 2. Long-term changes in water flow recorded at the Myosha River, (a) maximum annual water discharges (during the spring snowmelt period), (b) water runoff depth in the basin during the spring flood period.

works were carried out within the study area. But, in the absence of the regular maintenance of anti-erosion structures , their effectiveness reduced considerably. Hereby meaning the reduction in GHRR is more associated with changing meteorological conditions rather than with application of erosion control measures.

\section{Conclusions}

A decrease in the GHRR from $1.6 \mathrm{~m} \mathrm{yr}^{-1}$ (1983-1994) to $0.4 \mathrm{~m} \mathrm{yr}^{-1}$ (2015-2018) was established for the Western PreKama region of the Republic of Tatarstan (European Russia), on the basis of monitoring and the interpretation of satellite images. The linear GHRR derived from the monitoring were found to be in good agreement with an estimate $\left(0.3 \mathrm{~m} \mathrm{yr}^{-1}\right.$ for 2004-2014) based on the interpretation of satellite images. The change of hydrometeorological conditions, especially winter air temperatures is the main reason for the decrease of GHRR. Land use and erosion control measures did not affect the development of gullying processes. The recent trend of a decline in gully erosion intensity was consistent with the earlier-reported decrease in soil erosion in the study area (Sharifullin et al., 2018).

Data availability. We used a database of gullies, which is part of the big database. I've added its in the text (Vanmaercke et al., 2016) and in the references. Part of the data of gullies was resently received during fieldwork and was not been published In addition, meteorological information about daily precipitation data were provided by the RIHMI World Data Center (http://aisori-m.meteo.ru/ waisori/, RIHMI World Data Center, 2018). Information about hydrological characteristic was downloaded from Automated information system of the state monitoring of water bodies (AIS SMWB) (https://gmvo.skniivh.ru/, AIS SMWB, 2018) and were collected from Hydrological Yearbooks, which are available-only in printed version.

Author contributions. VG. conceived the idea of gully erosion assessment and correct the text. AS wrote the manuscript with support by BE and AG. RM and AD collected and analysed the data of gully erosion.

Competing interests. The authors declare that they have no conflict of interest.

Special issue statement. This article is part of the special issue "Land use and climate change impacts on erosion and sediment transport". It is a result of the ICCE Symposium 2018 - Climate Change Impacts on Sediment Dynamics: Measurement, Modelling and Management, Moscow, Russia, 27-31 August 2018. 
Acknowledgements. This work was funded by the Russian Foundation for Basic Research, project no. 18-35-00326 (fieldwork on measuring GHRR), and Russian Science Foundation, project no. 19-17-00064 (data collection on hydrological and meteorological parameters).

Financial support. This research has been supported by the Russian Foundation for Basic Research (project no. 18-35-00326) and Russian Science Foundation (project no. 19-17-00064).

\section{References}

Apukhtin, A. V. and Kumani, M. V.: Recent changes in the conditions of spring floods of rivers in Kursk region, Elec. Sci. Jour. of the Kursk. St. Univ., 1, 300-311, 2012 (in Russian).

AIS SMWB (Automated information system of state monitoring of water bodies): Hydrological characteristic, https://gmvo.skniivh. ru/, last accessed 10 November 2018.

Butakov, G. P., Dvinskih, A. P., Nazarov, N. N., and Rysin, I. I.: Modern gully erosion in the east of the Russian Plain, Geomorfologiya, 2, 43-46, 1987.

Dedkov, A. P. (Ed.): Ovrazhnaya eroziya vostoka Russkoy ravniny (Gully Erosion in the East of the Russian Plain), Kazan: Kazan State University (Publ.), 142 pp., 1990 (in Russian).

Dokuchayev, V. V.: Izbrannye trudy (Selected papers), edited by: Polynova, B., Moscow: Publishing House of the Academy of Sciences of the USSR, 223 pp., 1949 (in Russian).

Golosov, V., Yermolaev, O., Rysin, I., Vanmaercke, M., Medvedeva, R., and Zaytseva, M.: Mapping and spatial-temporal assessment of gully density in the Middle Volga region, Russia, Earth Surf. Proc. Land., 43, 2818-2834, 2018.

Ivanov, M. A., Prishchepov, A. V., Golosov, V. N., Zalyaliev, R. R., Efimov, K. V., Kondrat'eva, A. A., Kinyashova, A. D., and Ionova, Yu. K.: Changes of cropland area in the river basins of the European part of Russia for the period 1985-2015, as a factor of soil erosion dynamics, Sovremennye Problemy Distantsionnogo Zondirovaniya Zemli iz Kosmosa, 14, 149-157, 2017.
Kern, E. E.: Ovragi, ikh zakrepleniye, obleseniye i zapruzhivaniye (The gullies, its consolidation, afforestation and damming), Moscow: State publishing house, 163 pp., 1928 (in Russian).

RIHMI World Data Center (Russian Research Institute of Hydrometeorological Information - World Data Center Hydrometeorology data service system): meteorological information about daily precipitation data, http://aisori-m.meteo.ru/waisori/, last accessed: 12 December 2018.

Sharifullin, A. G., Gusarov, A. V., and Golosov, V. N.: Assessment of contemporary erosion/sedimentation trend within a small cultivated catchment in the Republic of Tatarstan (European Russia), Geomorfologiya, 3, 93-108, 2018.

Stupishin, A. V., Duglav, V. A., and Lapteva, N. N.: Geograficheskiy analiz ovrazhno-balochnykh sistem $\mathrm{v}$ predelakh Tatarskoy ÀSSR (Geographical analysis of gully/dry valley systems in the Tatar ASSR), Kazan: Kazan State University, 152 pp., 1980 (in Russian).

Valentin, C., Rajot, J. L., and Mitja, D.: Responses of soil crusting, runoff and erosion to fallowing in the sub-humid and semi-arid regions of West Africa, Agr. Ecosyst. Environ., 104, 287-302, 2004.

Vanmaercke, M., Poesen, J., Mele, B. V., Demuzere, M., Bruynseels, A., Golosov, V., Bezerra, J. F.-R, Bolysov, S., Dvinskih. A., Frankl, A., Fuseina, Yu., Guerra, A. J.-T., Haregeweyn, N., Ionita, I., Imwangana, F. M., Moeyersons, J., Moshe, I., Samani, A. N., Niacsu, L., Nyssen, J., Otsuki, Yo., Radoane, M., Rysin, I., Ryzhov, Yu. V., and Yermolaev, O.: How fast do gully headcuts retreat?, Earth-Sci. Rev., 154, 336-355, https://doi.org/10.1016/j.earscirev.2016.01.009, 2016.

Zorina, E. F.: Geografiya ovrazhnoy erozii (Geography of gully erosion), Moscow: MSU, 324 pp., 2006 (in Russian). 